\title{
The Cultural Comparative Study of the Roma Community and Bohemians. Prolegomena
}

\begin{abstract}
The submitted article is based on a fragment of a thesis entitled "The Image of the Roma and Artistic Bohemia in the Literature of the Young Poland". The subject matter of the research is the description of two communities living in the period of the Young Poland: the Roma people, and Bohemians. The adopted research method embraces the range of broadly defined anthropological research, including analysis and interpretation of texts in a cultural context, and, above all, various aspects of life referring to Bohemians and the Roma community in Poland at the turn of the $19^{\text {th }}$ and $20^{\text {th }}$ centuries. The research objective of this article is to show the similarities and differences between Bohemians of the Young Poland and the Roma living in this period, concerning originality of their lifestyle, customs, outfit and other phenomena. The in-depth analysis of the life aspects of the Roma and Bohemians from the Young Poland has demonstrated the similarities and differences between the two groups. They both functioned as "others" who had no relationship with the society. They were accompanied by a sense of loneliness, outsiderness, consciousness of rejection, tragedy of their situation and a sense of incomprehension and injustice.
\end{abstract}

\section{Keywords:}

bohemia, Romani people, Gypsies, the Young Poland, culture

According to the Practical Dictionary of Contemporary Polish, the word Roma is derived from the Greek athinganos and means a person who does not want to touch or to be touched. The term defines a member of the Indo-European nomadic tribe, scattered for centuries throughout the world (Zgółkowa, 1996, p. 321). In turn, the

Institute of Polish Philology, Philological Department, University of Wrocław, Poland, E-MAIL: justyna.matkowska@uwr.edu.pl 
Etymological Dictionary of the Polish Language says that the name of the Roma defined people from wandering tribes of Indian origin, known in Poland since the $14^{\text {th }}$ century (Bańkowski, 2000, p. 207). The word bohemia comes directly from the word Roma and defines a loose, friendly group of artists whose lifestyle was a form of protest against the customs and manners at the turn of the $19^{\text {th }}$ and the $20^{\text {th }}$ centuries (Zgółkowa, 1996, p. 322). The term la boheme (Robert, 2016, p. 270) is a specific translation of the French term la bohème, defining a group which brings together people living on a day-by-day basis, outside the socially accepted norms. Originally, in relation to la bohème, the word bohemia is the Latin name of the historical land called Bohemia (French Bohême - the Czech land). The etymological dictionary explains that a Bohemian is a resident of the Czech land, a hobo, a Roma person or an itinerant actor (Bańkowski, 2000, p. 207). The cited dictionaries clearly indicate the origin of the concept of bohemia from the word Roma, which allows me to carry out comparative research on the two groups.

\section{THE ORIGIN OF THE ROMANI PEOPLE AND ARTISTIC BOHEMIA}

The Roma are a nation of Indian origin (Mróz, 1971, p. 215) creating a diaspora which resides in most states around the world. It is a community with a distinct language and culture, and different traditions as well. Although the cradle of the Roma is India, they had to leave the country as early as the tenth century as a result of numerous military invasions and conflicts. After leaving India, the ancestors of the Romani people headed towards Persia and Afghanistan. Then they divided into two groups. The first one went through Armenia, the Caucasus and made for Russia and Scandinavia. The other group set off up the Euphrates and the Tigris, and again split into two smaller groups, one of which went to the Black Sea, the other to Syria, then through Palestine and Egypt to the whole of North Africa. Probably a part of this group reached Gibraltar and Spain. Most of the refugees headed for Greece, and then towards the Balkan Peninsula and later made their way to Central Europe. Some of them subsequently went to America and Australia (Mróz, 1971, pp. 219-224).

The first uncertified information which refers to the Roma in the Polish lands dates back to 1357. Roma first appeared in southern Poland (Mróz, 1971, p. 179). Old municipal and landed records mention the village of Cyganowice in the parish of Nowy Sącz. Additionally, one can find the oldest information about the presence of Roma community in Polish lands in the source of $9^{\text {th }}$ November 1401. It concerns Mikołaj Cygan who made a payment of the rent for Zabłocie (Zapłocie) (Mirga \& 
Mróz, 1994, p. 52). The surname of Roma appears in church registers of the dukes of Mazovia in 1417-1433. The mentions of Roma also appeared in the court files of Sanok town, where a peasant named Cygan (Gypsy) coming from Królikowa village is mentioned in the record dated from 1428, and in another one (from 1436) we read about peasants Jan and Jakub Cygan (Gypsy). In turn, the records of Lviv from 1445 indicate a nobleman - Jan Cygański. In the files of Sambor town before 1445 there are mentions of a nobleman called Jan Czygański. In 1487, there was a topographical name Cyhanowa Łuka, and before 1503 a settlement of Cyganowo. In the $16^{\text {th }}$ century the village of Cyganowice a.k.a. Czigunowyce came into existence, owned by the convent of the Poor Clares of Sącz, which is now the hamlet of Stary Sącz (Ficowski, 2013, pp. 27-28).

All bohemians, like the Roma themselves, have their colourful pedigree. Already in the thirteenth-century Europe, in connection with the development of trade and building of towns, there were significant demographic changes which destroyed the social structures. At that time, a group of declassed people emerged, representing the mental proletariat and being a bunch of vagabonds hostile to social order and the Church. They created nomadic communities or brotherhoods, religious orders, sects of poets-goliards denouncing the social system, which condemned them to constant migration and homelessness. They were led by archpoets. The life programme of the goliards was contrary to formal rules of conduct. In the fight against common standards of life, statutes or rules, goliards' fraternities were created (Weiss, 1970, pp. 16-24).

Thomas Weiss refers to the study of Arnold Hauser, who pointed out the analogy between the $13^{\text {th }}$-century goliards, the $17^{\text {th }}$-century Polish picaros and the 19 thcentury Bohemians. In the $17^{\text {th }}$ century, Polish picaros were the type of intellectual and artistic bohemians, who wanted to rebuild and change the world. Most often they rebelled against all customs and traditions, creating new social, political, or aesthetic thoughts and ideas of general outlook on the world. According to Hauser, they were "journalists of the era" and they engaged in "distribution of culture". At the same time, however, their situation was awful, living on the margins of society, in which there was no place for them (Weiss, 1970, pp. 16-22).

The term bohemia denoting a literary group comes from the title of the book from 1849 "Scenes from the life of Bohemia" by Henry Murger (1948) in which artists living in Paris in the 40s of the $19^{\text {th }}$ century are described (Weiss, 1970, pp. 5-9). The terms such as artistic bohemia, bohemian, Bohemians are used to name a group of artists working during the period of the Young Poland in Cracow. These concepts were used as well to call the clusters of artists working in Warsaw during the Romantic era, the so-called $19^{\text {th }}$-century bohemian Warsaw 
(Zgółkowa, 1995, p. 124), whose genesis was based on the ideological objectives and premises of general outlook on the world. They manifested their otherness by poverty and alcoholism. Members of the group shaped the reality in imitation of art and experienced it as a real work of art, and declared their views in literary works. They had their meeting place at Miramka inn, where they ate, drank, discussed and created. This group took up social, ideological problems and issues of general outlook on the world in their literary works. They were dominated by the type of an artist-enthusiast, an advocate of ideas and dreams of their implementation (Weiss, 1970, pp. 38-39).

However, almost half a century later, the Young Poland's Bohemians existed and worked mainly in Cracow, where just before the outbreak of the idea of early modern period (the decade 1880-1890) intensive discussions of general outlook on the world were conducted, mainly caused by the collapse of optimistic faith in the efficacy of the theory and practice of positivism.

\section{THE LANGUAGE OF THE ROMANI PEOPLE AND THE LANGUAGE OF BOHEMIANS. SOME COMMENTS}

Romani language belongs to the Indo-Aryan branch of the Indo-European language family. It is similar to Hindi and ancient Sanskrit. A significant impact on the development of the language is also the fact that the Roma are bilingual. In addition to the Romani language, they speak the language of the country where they live. This has an impact on the unconscious transfer of individual words and even whole phrases, expressions and structures from the language of the people among whom they live, to their own. Borrowed words are often adapted to grammatical rules and the phonology of the particular language (Mróz, 1971, pp. 194-206). In contrast, the European literary and artistic bohemia spoke a jargon, a language full of hyperbolic expressions and neologisms. They created a vocabulary, in which conventional word marks were used, understandable only to the initiated ones (Weiss, 1970, p. 31).

\section{CUSTOMS OF THE ROMA AND BOHEMIANS FROM THE YOUNG POLAND}

In the 50s and 60s of the $19^{\text {th }}$ century, new waves of the Romani people, different than the locals, began arriving at the grounds of the former Republic of Poland. They were dressed more colorfully and more richly and spoke their own dialect, 
different from the speech of the Polish Roma. They were two large tribes: the Kelderari, or Kelderash, from Romania and Hungary, and the Lovari from Transylvania. The first one dealt with coppersmithing and related crafts, and the others traded horses. Around 1870, the Hungarian Roma came to Poland earning their living trading in a variety of goods, and in the 90 s of the $19^{\text {th }}$ century, there was an influx of even smaller groups, which after some time were absorbed by the Kelderash. They included: the Ursari, or Bear Tamers, and the Ćurari, making sieves and riddles. The Kelderash, called coppersmiths, were very wealthy because of their profession and were contemptuous of the Roma locals, much of them poorer and living much more modestly (Ficowski, 2013, pp. 107-110).

The last decades of the $19^{\text {th }}$ century and the first years of the $20^{\text {th }}$ century were a period of remarkable intensity of Roma migration around Poland. At that time even settled Romanis set off to return to a nomadic lifestyle. They included the Roma from some settlements of Galicia in the Pokucie Region and a group of socalled Zlotars, or Dzvonkars, dealing with casting bells in bronze and brass, as well as producing various metal utensils and jewellery (Ficowski, 2013, pp. 113-117).

At the end of the $19^{\text {th }}$ century, the Roma settlement began in the belt of the Podkarpacie Region and in the Tatra Mountains, where they lived in dugouts and poor peasant cottages and worked as masons and smiths (Ficowski, 2013, pp. 205-216). The basic unit of the Roma organisation was a train of caravans, which consisted of a few to a dozen families. It was led by a leader (alderman), also called Wajda, Wojda or Wataf. He was a representative of the Roma who dealt with fixing all issues with state authorities, arbitrating disputes, approving marriages. He decided on the destination, and when and where to make a stop, as well as any other matters within the community (Mróz, 1971, pp. 130-138).

The Bohemia of the Young Poland was a group of artists from Cracow who openly manifested their aesthetic views and often remained in conflict with the recipients of their works. At the turn of the $19^{\text {th }}$ and $20^{\text {th }}$ centuries, a Roma person was the representative of the age of the crisis of all values, a rebellious and conflicted with society, an outsider. A characteristic feature of this era is a comparison between the creation of art and prostitution. A prostitute is a cool observer of passion and a symbol of a rebel who is opposed to commonly accepted norms and principles. She remains beyond the ethical and moral convention. An average townsman, respecting a set of established standards, was a follower of propriety, dull mediocrity and stability. The lifestyle of artists was the opposite of this attitude. The awareness that they prostitute themselves as creators, giving their feelings to the audience, whom they despised, repelled them from the rest of society, from which they were excluded anyway (Weiss, 1970, pp. 53-55). 
Customs of the Cracow bohemia consisted of general outlook on the world and a sense of their own otherness and superiority in relation to society. Members of the group did not adapt to the standards and principles of behavior respected by other citizens. Customs of Bohemians of the Young Poland were an aware protest against philistinism and arose due to mental differences of the people belonging to the group. Artists made efforts to avoid stability in their lives, which is confirmed by numerous novels and dramas, showing the world of an artist protagonist. One of the fully aware choices of Bohemians, due to intolerance of the philistine way of earning a living, was poverty. Weiss points out that most of the real Bohemians lived in extreme poverty due to dedication, devotion and service to arts, which required full freedom and independence. Joining this environment involved deliberate breaking with the norms of behaviour and general outlook on the world (Weiss, 1970, pp. 136-137).

The equivalent of a Shero Rom, who was the leader of a Romani train of caravans, for the Cracow bohemia was Stanisław Przybyszewski. The writer was an arch-model of a Bohemian and an ideal to follow for representatives of the generation of the Young Poland's bohemia. He stood out thanks to his personality, lifestyle and lack of basic moral principles. All these features affected Przybyszewski's alienation from society (Weiss, 1970, pp. 63-77). His attitude to women, relationships and marriages were well known to the public, and classic love triangles and squares repeated in his life very often. He committed all his experiences and love impressions to paper and shared them with readers and an audience. He lived carelessly, on a day-to-day basis, without thinking about the future and about any stability. He was very hospitable and open. Przybyszewski was aware of his mission, attitude, lifestyle that was consistent with his ideology and constituted implementation of the propounded theories. He manifested his views, and constantly provoked in the field of ethics and morality. In his journalistic statements, he did not hide his hostility and contempt for a philistine, a bourgeois, a crowd, and society (Dynak, 1994, pp. 36-39). Przybyszewski had alcoholic tendencies, which he had never been hiding. He believed that without stimulants it was difficult to endure boredom and tragedy of human life. He knew that alcohol was destroying him, but nevertheless, for a time it increased mental strength and numbed nerves, so that they would lose sensitivity to pain and suffering. Przybyszewski wanted others to believe that he lived and behaved so due to an internal imperative, which demanded from him to lead such a bohemian life. A very important feature of the bohemian customs was light-heartedness and desire for fun and entertainment, which allowed bohemians to forget about the dull and sad reality (Weiss, 1970, p. 150). 


\section{MEeting PLACES OF THE ROMA PEOPLE AND BOHEMIANS}

The home of the Romani people was a caravan and a tent, but from autumn to spring, they wintered indoors. The first mention of the use of tents by the European Roma comes from the $14^{\text {th }}$ century, and the then sources say that, initially, after arriving in Europe, they built shelters out of branches and leaves. In the beginning, Roma tents were transported by horses, donkeys or worn on the back. In the $18^{\text {th }}$ and $19^{\text {th }}$ centuries, the Roma began to buy caravans from the rural population. At first, they were used to carry belongings, but at the turn of the $19^{\text {th }}$ and $20^{\text {th }}$ centuries some of them were converted into mobile homes. Some Romani people rode caravans covered with canvas pulled on U-shaped arches. The others travelled in mobile homes, which were covered with a roof. The mobile homes, which belonged to the wealthy Roma, were often glazed and decorated with paintings, and wooden dragons and griffins as well. The caravans were turned into a singleroom flat with a sleeping place, a dining table and a kitchen. Inside there were also cupboards for appliances, pictures of family members and other images. The windows were covered with net curtains and decorated with flowers (Mróz, 1971, pp. 88-110). During the summer migration, the Roma women cooked on bonfires, and entire families slept in tents that were built of poles and pegs, covered with long and wide sheets of canvas (Ficowski, 2013, pp. 221-222).

The nature was the real element of the Roma, and mainly the forest and green meadows. In the evenings, Romanis met right there, in the surroundings closest to their heart. In forest clearings they played, sang and danced, trying to forget about the reality that surrounded them. A nomadic lifestyle brought in not only specific meeting places to their world, but also a lot of skills useful in everyday life. One of them was a broad knowledge of the medicinal properties of plants, herbs, and other gifts of nature.

Meeting places of the Bohemians of the Young Poland were completely different from the ones close to the Romani people. The Bohemians from the Young Poland met mostly in cafés, where they discussed, had fun, but also consumed alcohol to ease the "pain of everyday life” (Weiss, 1970, pp. 143-144). Using social provocation, bohemia emphasized hostility to the world of philistines and strived to ensure that restaurants and cafés they attended became the exclusive places (Weiss, 1970, p. 151). Cracow Bohemians also met in private homes. ${ }^{2}$ One of those places was Ignacy Sewery-Maciejowski's three-room flat, which was on Batory street in Cracow. Among the visitors there were Stanisław Wyspiański,

\footnotetext{
2 See information about meeting places of the bohemians in: Bajda, 2003.
} 
Stanisław Przybyszewski, Jacek Malczewski, Ignacy Daszyński, Adam Asnyk, the Reymont family, Wincenty Lutosławski, and many others. In this flat almost every day for nearly a decade the elite of Polish artistic life gathered. Schmidt's café is considered the first truly artistic cafe in Cracow. At first, the regulars were mainly Włodzimierz Tetmajer and Ignacy Daszyński, but soon they were joined by Stanisław Wyspiański, Lucjan Rydel, Kazimierz Tetmajer, Gabriela Zapolska, Adolf Nowaczyński and Maciej Szukiewicz, who immortalized the place in one of his poems in the 40 s of the $20^{\text {th }}$ century. The cafe was a retreat for artists and a group of intellectuals of Cracow. There the poets wrote their poems, the painters found inspiration, thanks to which their works were created. Another café, where Bohemia moved to directly from Schmidt’s, was Turliński’s café, located on Szpitalna street on the ground floor of a small tenement, which quickly became famous and known as the Paon (a peacock).

\section{OUTFIT OF THE ROMA PEOPLE AND OUTFIT OF BOHEMIANS}

For centuries, the Roma dress went through numerous changes. However, the characteristic features of female outfit remained, first of all, a long-pleated skirt and a scarf hanging over one shoulder and colorful ornaments; whereas men always wore long hair and thus they distinguished themselves from strangers (Ficowski, 2013, pp. 225-226). The Roma did not have a distinct folk costume. It differed depending on the country and the whereabouts of the given group. The nomadic lifestyle allowed them to transfer some elements of clothing and some other details from their previous locations. The most distinctive were women's clothes, which stood out because of their colourfulness, floral motifs and the length of skirts. According to tradition, the $19^{\text {th }}$-century Roma dress was richly decorated. It was characterized by the brightness of colours, and often it was also decorated with gold coins or silver buttons. The women improved their looks with necklaces and pendants, resembling coins in shape, and as earrings they wore large wheels. The men also wore earrings and all kinds of pendants, charms, rings and bracelets (Mróz, 1971, pp. 43-52).

In the book “The Roma on the Polish Roads” Jerzy Ficowski (2013) referred to a detailed description of the Romani costume in Lithuania from the 1880s. According to this reference, the men wore long black coats, similar to Jewish gaberdines, decorated with two rows of silver buttons. On their heads, they had black felt hats with a round brim and around the neck - black scarves tied at the back. On the right side of a wide belt they hung a moneybag, on the left - a horsewhip. 
They were attired in black trousers ornamented with red ribbons, sewn along the legs. Unmarried Roma women put on small black caps brightened up with flowers and ribbons, and ears were ornamented with long silver earrings, while married women wore red scarves on their heads. Silver and gold coins were used as necklaces or elements they plaited their hair with. Some wealthy groups settled in cities, especially the clan of the Lovari, retained only a tendency to wear magnificent jewellery, but abandoned a distinct outfit (Ficowski, 2013, pp. 226-229).

Also, among the Bohemians of Cracow the clothing style played an important role in emphasizing the otherness and it was a protest against bourgeois society. The clothes were a cultural part of the age. We should take into account, however, that the vast majority of works written by the Bohemians of the Young Poland present mainly their "state of mind", and do not contain much information about their clothing. The basic dogma of the culture was in fact a conviction of the unique role of the artist, their intellectual and emotional qualities. Decadent slogans, rebellion against society, alienation and violation of moral and social standards were evident in the attitude of the modernist bohemians. It should be noted, however, that the bohemian outfit of the Young Poland expressed a desire to break with dullness and uniformity of the contemporary men's outfit. This led to the individualisation of appearance. The main distinguishing features of the then bohemian outfit were a black cape, a hat with a wide brim or a large beret and sheepskin waistcoats, fur coats in Zakopane style, peasant shirts. A very important feature that differed the Young Poland's bohemia from the Western bohemians was the introduction of folk accents to the clothing style of artists, which were ideological manifestation of excessive idealisation of the peasantry and rebellion against reality (Sieradzka, 2003, pp. 17-29).

\section{ACTIVITIES OF THE ROMA PEOPLE AND BOHEMIANS}

The first mentions about the Roma residing in Europe say that Roma women dealt mainly with witchcraft, fortune-telling, and selling amulets and magical medicines. Permanently for centuries among the men there were popular professions such as musicians, dancers, animal trainers, artisans and blacksmiths. The Roma performed craft services for farmers, manor houses and the military. They were involved in the broadly defined trade, mainly of horses. Jerzy Ficowski states that according to chronicles from the period of the $16^{\text {th }}$ to $18^{\text {th }}$ centuries, on the Polish territory Romanis were increasingly valued and employed in urban strongholds as gunsmiths and craftsmen. Some of them, at the request of the authorities, went 
then to a settled way of life. However, the settlement of the Roma was not beneficial for local craftsmen associated in guilds, for which they became competitors. The guilds attempted to introduce regulations limiting the scope of jobs that Roma could perform. In Hungary, according to the census of 1739, Roma blacksmiths accounted for $22.5 \%$ of all the blacksmiths in the country. They were involved in shoeing horses, hobnailing boots, making locks and coppersmithing. As a result of the development of industrial production, their role decreased in importance since the mid- $19^{\text {th }}$ century. There were also Roma blacksmiths who travelled on foot with their belongings and forging tools, as they were too poor to buy a horse and a caravan (Mróz, 1971, pp. 53-55).

Along the Carpathian Belt, the Roma people delivered pots, sheep and cow bells and ferrules on clubs and canes to shepherds. Locksmithing, galvanising vessels (tin plating) and goldsmithing should be distinguished among the Roma professions. Another occupation in addition to horse trading was their treatment, as well as bear training. The job was popular in Lithuania, where Romanis established the so-called Smorgon Academy. They taught bears how to dance and perform tricks that were shown then in different countries. The Roma were engaged in agriculture and gold leaching from the sand of mountain streams using primitive tools (Mróz, 1971, pp. 58-83). Other popular Romani professions were also sieve-making and coppersmithing. The tribe of the Kelderash dealt with making copper pots, caldrons and pans, tin plating of copper boilers, butcher hooks and other vessels with tin, which they prepared in a mysterious way (Ficowski, 2013, pp. 275-276).

An immemorial Roma profession was playing music. The Roma folk music has been alive and permanent for centuries, and certainly the representatives of this community have music in the blood and in their hearts. Wherever there are Roma, you can meet them playing, singing and dancing. The Roma bands played at weddings, in taverns, as well as at the courts of Polish kings. Jerzy Ficowski mentions outstanding Roma court musicians: Janczy, who was a bagpiper to King Władysław IV, and a folk musician to Queen Marysieńka Sobieska (Marie Casimire). The violin, dulcimer, lute, harp, guitar and accordion were favourite instruments used by Roma. The bands they created were made up of family members (Ficowski, 2013, pp. 275-276).

In the ranks of the Bohemians of Cracow there were artists such as painters, writers, actors, musicians. The practice of art was both compulsion and a need of a true creator. The artist gifted with intuition revealed to the audience the unknown world and secrets invisible to ordinary people (Weiss, 1970, pp. 120-121). Talent was a gift that needed to be sacrificed for and one should become its priest. These 
words are a direct reference to a loud artistic manifesto Confiteor (Przybyszewski, 1977, pp. 235-243) by Stanisław Przybyszewski. According to the archbohemian, art is a reproduction of the life of soul and the highest religion, and its priest is an artist who creates for the crowd. The most intimate content of his soul reached people through his works, however they were not able to evaluate and appreciate his output. Awareness of writers taking up criticism of tragic imagination was associated with the hostile attitude of the artist to society. An experience of pain, suffering and tragedy was the condition for granting the right to creative work (Weiss, 1970, pp. 123-135).

\section{CONCLUSION}

The Roma and the Bohemians of Cracow stood out from the rest of the society living in the era of the Young Poland. The surveyed life aspects of the Roma community and Bohemians from the Young Poland show the similarities and differences between the two groups. They functioned as "others", i.e., people having no relationship with the public. They were accompanied by a sense of loneliness and outsiderhood, awareness of rejection, tragedy of their situation and a sense of incomprehension and injustice. They differed from the rest of the population living on the Polish territory in the period of the late $19^{\text {th }}$ and early $20^{\text {th }}$ centuries. Both groups seemed also conscious of their dissimilarity and originality.

Bohemia was a group of artistic personalities for whom the art was the highest value. They manifested their distinct manners also through their clothing and behaviour. What distinguished them from others was protest, rebellion, negation and provocation. Members of artistic groups represented diverse interests, views and professions. They shared a dislike for the present and the desire for a better future. Their lifestyle did not affect positively contacts and relationships with others. They lived in poverty, from day to day, without thinking of the future, and all the time they were accompanied by art and music that helped them survive the fatality of the situation they were in.

Bohemians stood out for their lack of moral, social and ethical norms, whereas Romanis respected an unwritten code of social prohibitions called the Mageripen. Both groups were united by rejection and awareness of otherness and individualism, as well as incomprehension and the lack of acceptance by the rest of society. Bohemians were excluded from society, but - paradoxically - the goal of their artistic activity was an attempt to copy life. Members of the Cracow bohemia 
were the living manifestation of their master’s (Stanisław Przybyszewski) general outlook on the world (Weiss, 1970, pp. 50-61).

The Bohemians of Cracow took refuge among the city walls, in cafés or in well-known private homes, while the nature was the element of the Romanis, and particularly they were fond of forests and meadows. For centuries the tradition of Roma, that is eternal wanderers, has been associated with the colourful caravans, colourful skirts swirling in a spontaneous dance, wistful romances sung around campfires and the sound of strings and the very beautiful, longing voice of the violin.

The two groups differed in performed professions. The Bohemians of Cracow included artists, mainly poets, memoirists and painters. However, the Romani occupations were a lot more varied. Among other things, the Roma dealt with trading, coppersmithing, blacksmithing, craft, animal training, fortune-telling, and music. A common feature of both groups was the practice of art, which also was supposed to be their way of life.

Undoubtedly, the two groups differed in clothing from the rest of society. The Roma dressed in accordance with a centuries-old tradition, whereas bohemia manifested their own views through their outfit, tried to individualize it and deliberately provoked with the way they dressed. Clothing played an important role in emphasizing the dissimilarity of artists and was a protest against bourgeois society.

Undoubtedly, bohemian artists followed the Roma in terms of certain characteristics of customs, items of clothing, living from day to day and detachment from material goods. However, in addition to the common features, some differences should be taken into account, such as the place of communion, professions, with the exception of making art, and moral principles. Unfortunately, the Polish society, as well as other nations do not realize the richness of the Roma culture, which for centuries has remained Oriental and mysterious. This is also because Roma zealously guard secrets of their customs, traditions, culture and language.

\section{References}

Bajda, J. (2003). Poezja a sztuki piękne. O świadomości estetycznej i wyobraźni plastycznej Kazimierza Przerwy-Tetmajera. Warszawa: Wydawnictwo DiG.

Bańkowski, A. (Ed.). (2000). Etymologiczny słownik języka polskiego. Vol. 1. Warszawa: Wydawnictwo Naukowe PWN.

Berent, W. (1998). Próchno. Series I, No. 234. Wrocław: Biblioteka Narodowa.

Dynak, J. (1994). Przybyszewski: dzieje, legendy i autolegendy. Wrocław: Towarzystwo Przyjaciół Polonistyki Wrocławskiej.

Ficowski, J. (2013). Cyganie na polskich drogach. Warszawa: Wydawnictwo Nisza. 
Kisielewski, J.A. (1903). Karykatury: Komedia. Kraków: Towarzystwo Autorów i Wydawców Prac Naukowych Universitas.

Kisielewski, J.A. (2002). W sieci. Kraków: Universitas.

Kolberg, O. (1882). Pokucie. Obraz etnograficzny. Vol. I, Kraków: Akademia Umiejętności.

Łoch, E. (Ed.). (1980). Jan August Kisielewski i problemy dramatu młodopolskiego. Rzeszów: Towarzystwo Naukowe w Rzeszowie.

Mirga, A., \& Mróz, L. (1994). Cyganie. Odmienność i nietolerancja. Warszawa: Wydawnictwo Naukowe PWN.

Mróz, L. (1971). Cyganie. Warszawa: Książka i Wiedza.

Murger, H. (1948). Sceny z życia cyganerii. Transl. by T. Boy-Żeleński. Warszawa: Wydawnictwo Wiedza.

Narbutt, T. (1830). Rys historyczny ludu cygańskiego. Wilno: A. Marcinowski.

Okulicz-Kozaryn, R. (1995). Mała historia dandyzmu. Poznań: Obserwator.

Przesmycki, Z. (1977). Harmonie i dysonanse. In: M. Podraza-Kwiatkowska (Ed.), Programy i dyskusje literackie okresu Młodej Polski (pp. 175-182). Wrocław-Kraków: Ossolineum.

Przybyszewski, S. (1977). Confiteor. In: M. Podraza-Kwiatkowska (Ed.), Programy i dyskusje literackie okresu Młodej Polski (pp. 218-224). Wrocław-Kraków: Ossolineum.

Robert, P. (2016). Le Petit Robert: Dictionnaire alphabétique et analogique de la langue française. Paris: Le Robert.

Sieradzka, A. (2003). Nie tylko peleryna. Moda okresu Młodej Polski w życiu i sztuce. Warszawa: Wydawnictwo DiG.

Weiss, T. (1970). Cyganeria Młodej Polski. Kraków: Wydawnictwo Literackie.

Zgółkowa, H. (Ed.). (1995). Praktyczny słownik współczesnej polszczyzny. Vol. 5. Poznań: Wydawnictwo Kurpisz.

Zgółkowa, H. (Ed.). (1996). Praktyczny słownik współczesnej polszczyzny. Vol. 7. Poznań: Wydawnictwo Kurpisz. 